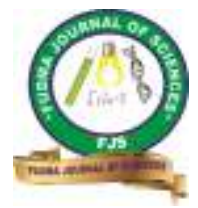

FUDMA Journal of Sciences (FJS)

ISSN online: $2616-1370$

ISSN print: 2645 - 2944

Vol. 5 No. 1, March, 2021, pp $529-538$

DOI: https://doi.org/10.33003/fjs-2021-0501-600

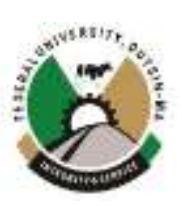

\title{
DETERMINANTS OF HOUSEHOLD'S POVERTY AMONG CROP FARMERS IN KADUNA STATE, NIGERIA
}

\author{
${ }^{* 1}$ Adamu, B. D., ${ }^{2}$ Tanko, F., ${ }^{2}$ Barnabas, T. M. and ${ }^{3}$ Adejoh, E. U. \\ ${ }^{1}$ Department of Agricultural Extension and Rural Development, Faculty of Agriculture, Ahmadu Bello University Zaria, Kaduna \\ State, Nigeria. \\ ${ }^{2}$ Department of Agricultural Economics and Farm Management Technology, Federal University of Technology Minna, Niger \\ State, Nigeria. \\ ${ }^{3}$ National Agricultural Extension and Research Liaison Services (NAERLS), ABU, Zaria, Kaduna State, Nigeria
}

*Corresponding Author's Email: danbaba3@gmail.com 08065480011

\begin{abstract}
This study examined the households' poverty status among crop farmers in Kaduna State. Multi-stage sampling procedure was used to select 242 farmers for this study. Data were collected through using structured questionnaire with the help of trained enumerators. Descriptive and inferential statistics such as tobit regression and Foster, Greer and Thorbecke (FGT) model was employed in this study. The results showed that the mean age of the respondents was 45 years and were married, mean household size of the farmers was 11 persons, and about $(80.6 \%)$ had formal education. The poverty situation of the farmers revealed that $51 \%$ were poor and the strategies adopted by the farmers to combat poverty were mostly through diversification into commercial farming, increased personal savings and involvement in non-farming activities. Tobit regression analysis revealed that age, household and income negatively influences the poverty status of the farmers, statistically significant at $1 \%$, this implied that, poverty is concentrated among households in the study area. Major constraints encountered by the crop farmers, include high cost of inputs, inadequate credit facilities and inadequate market linkages. In conclusion, poverty incidence had a negative and significant effect on rural crop farmers. It was recommended that farmers should form cooperative societies to access micro loan; farmer should be linked to the urban market through extension agent and media to attract good value for their crops. Government and Non-Governmental Organizations (NGOs) should make farm inputs readily available at a subsidized rate.
\end{abstract}

Keywords: Determinants, Households' poverty, Crop farmers and Kaduna State

\section{INTRODUCTION}

Agriculture in Nigeria has been the most important sector of the economy from history and a basis for rural employment, food production and major export earnings before the discovery of black gold (Oni, 2008). The assertion made above was based on the evidence that as at pre-independence to independence little was known of petroleum as a major source of revenue for Nigeria. The National agricultural system was able to produce food crops like, maize, sorghum, millet and soya beans to the extent that there was almost no need for importation ((Ogunlela and Ogungbile, 2014). In addition to these food crops, there was sustained emphasis on agriculture to the extent that Nigeria was a net exporter of such agricultural commodities like cocoa, palm produces, rubber and cotton (IFPRI, 2018) Hitherto, agriculture accounted for over $60 \%$ of the National Gross Domestic Product (GDP) between 1960-1970, but fell drastically to $28.4 \%$ in 1971-1980 ((Adenomon and Oyejola, 2013). However, with the advent of petroleum in the early 1970 s, petroleum became the country's major foreign earner and agriculture became grossly neglected (Oni, 2008).

Poverty has been a lingering problem in Nigeria and mostly affects the rural economy, which is the dwelling place for over
$70 \%$ inhabitants who depend mainly on agricultural production for livelihood. Nigeria has about 79 million hectares of arable land of which 32 million hectares are cultivated. Over $90 \%$ of agricultural production is rain-fed, smallholders, mostly peasant account for over $80 \%$ of all farm holdings (Nwajinba, 2012). Both crops and livestock remain below potential as a result of inadequate access to and low uptake of high quality seeds, little or no fertilizer use, inadequate or absence of farm machineries, low application of agrochemical and insufficient production system as a result of rural poverty (Yahaya, 2009)

The notion of poverty is determined in different ways by different institutions. The indicators of poverty also differ for ease of reference and coherence in global assessment. Development agencies use quantitative measures of poverty, such as those setting a threshold of one or two dollar a day. However, poverty has a number of definitions that have different measuring dimensions. The United Nations High Commission for Refugees (2004) defines "Poverty" as a human condition characterized by the sustained or chronic deprivation of resource capabilities choices, security and power necessary for an adequate standard of living and other civil, cultural, economic, 
political as well as social right. Thus poverty can be described as the state of being without the necessities of daily living, often associated with need, hardship and lack of resources across a wide range of circumstances.

The Copenhagen Declaration of 1995 describes absolute poverty as a condition characterized by severe deprivation of basic human needs including food, safe drinking, water sanitation facilities, health education, and information. World Bank (2019) on the other hand identifies "extreme poor" as people who live on less than \$1day. On that standard, $21 \%$ of the world's population was in extreme poverty, and more than half the world's population was poor in 2001 . However, the dollar a day poverty lines have been widely publicized, even many analyst (Reddy and Kakwani, 2006; Bhalla, 2002) have noted their shortcomings. They are of the view that poverty lines underestimate the actual extent of poverty. Reddy (2009) has suggested the possibility that some of the recent lines might themselves have been expediently put at the dollar a day mark. The improved World Bank poverty line of $\$ 1.25$ per person a day has been based on the average poverty line for the poorest 15 countries. Alternatively, Pogge and Reddy (2006) argued that, an inconsistent procedure with regard to correcting for rural - urban price differences, applying it only to cases of Indian and China.

Similarly, in 2015, the United Nations' Global MultiDimensional Poverty Index (MPI) has used three dimensions and 10 indicators in estimating Overall poverty in Nigeria, and each dimension is equally weighted, each indicator within a dimension is also equally weighted, and added. These three dimensions include: education, health and living standards. According to the Multi-Dimensional Poverty Index (MPI) Report (2019), about 54\% of Nigerians lived below the national poverty line. It also shows that the prevalence of poverty among the geo-political zone varied; North-east $76.8 \%$, North-west $80.9 \%$, North-central $45.7 \%$, South-east $27.38 \%$, South-west $19.3 \%$ and South-south $25.2 \%$. The urban poverty rate was $28 \%$, while the rural poverty rate was $70 \%$.Nigeria rural households are considered to be poor and hungry despite its abundant fertile land and other natural resources that could guarantee adequate crops production, but productivity have seriously declined over the years as result of rural poverty especially in developing countries like Nigeria (Folorunso, 2016). ). Rural poverty contributes to poor agricultural productivity, as many farmers in Nigeria cannot afford to purchase necessary farm inputs such as fertilizers, pesticides and improved seeds, which would bring about increased productivity. Also, the ability of poor consumers to purchase food necessary for maintenance of health and productive life is reduced. The fact that food security in Africa has greatly worsened since 1970 (Rosegrant et al; 2005) has resulted in decline in per capita consumption of food in some African regions in recent times (Ogunlela and Ogungbile, 2014). International Food Policy Research Institute (2018) reported that, food crops (cereal, roots and tuber crops) dominated Nigeria crop production and Nigeria is the world's leading producer of cassava yams cowpea and cereal crops. However, productivity is below potential yields with the farmer yields of most crops are less than half of the yield potential due to increased population pressure and high demand for land for nonagricultural uses which has led to decrease in available agricultural land and consequently small farm sizes resulting in low food production, low income, high food insecurity and high poverty prevalence despite the resource endowment of Nigeria (Igbenaese and Okojie-Okoedo, 2017). Although, concerted efforts have been made by past and present government of Nigeria towards improving agricultural productivity in alleviating poverty among rural farmers, yet millions of people in Nigeria are still poor and hungry (Simonyan et al., 2010). Hence, the role of increased productivity of cereal, root and tuber crop farms is no longer debatable but a great necessity in order to reverse the productivity of small farms in Nigeria, since cereal, root and tuber crops (maize, sorghum, millet, rice, wheat, cassava,yam and irish potatoes) have the potential for bridging the food gap, as they have been discovered from research that famine rarely occur where these crops are widely grown (Nweke et al.,2012)

Studies have been conducted on the determinant of poverty among rural farmers in Nigerian population. These include Oladimeji et.al. (2014), Simpa 2014, Adamu and Michael, (2019). However, there is scanty empirical information on the effects of households' poverty on farmers' crop productivity in Kaduna State. Against this background, this study was therefore, designed to determine the households' poverty among crop farmers in Kaduna State, Nigeria. Specifically, it describes the socio-economic characteristics of crop farmers, examine the poverty status and strategies adopted in mitigating incidence of poverty among crop farmers in the study area; and identify the constraints faced by crop farmers.

\section{MATERIALS AND METHODS}

\section{Description of the study area}

This study was conducted in Kaduna State Nigeria. The State is situated in the North - West geo-political zone of the country at about $200 \mathrm{~km}^{2}$ away from the Federal capital territory Abuja. It is located between latitude $9^{\circ} 04^{\prime}$ to $11^{\circ} 50^{\prime} \mathrm{N}$ and longitudes $07^{\circ}$ $09^{\prime}$ to $10^{\circ} 04^{\prime} \mathrm{E}$, respectively. It shares boundary with Katsina and Kano States to the North, Plateau State to the North East, Nasarawa State and Federal Capital Territory, Abuja to the South and Niger and Zamfara States to the West. The National Population Census (NPC, 2006), provisional census shows that the State has a population of $6,066,562$, and farm families of 606,007 (KADP, 2014), going by the population growth rate of $3.2 \%$ in Nigeria, the population of the State was projected population to be $9,428,842$ by 2020 .

\section{Sampling Procedure and Sampling Size}

Multistage sampling technique was used for the selection of respondents. In the first stage, one Local Government Area (Kagarko, Lere and Kudan) was randomly selected from each of the four agricultural zones; Samaru, Maigana, Birni-Gwari and Lere, respectively. In the second stage, three villages were randomly selected from each Local Government Areas chosen to give a total of twelve villages. In the third stage, respondents (farmers) were selected proportionately from the sampling frame of 23 total registered farm families in the study area obtained from Kaduna State Agricultural Development Project (KADP). (KADP, 2014). Lastly, a sample size of two hundred and forty-two (242) farmers which is ten percent $(10 \%)$ of the sampling frame was selected for this study. Data were collected through interview schedule using structured questionnaire with the help of trained enumerators under the supervision of the researcher. 
Table 1: Distribution of crop farmers in the Study Area

\begin{tabular}{|c|c|c|c|c|}
\hline Agricultural Zones & LGA & Villages & Sample Frame & Sample Size $10 \%$ \\
\hline \multirow[t]{2}{*}{ Samaru } & Kagarko & $\begin{array}{c}\text { DogoKurmi } \\
\text { Katugal }\end{array}$ & $\begin{array}{l}288 \\
149\end{array}$ & $\begin{array}{l}29 \\
15\end{array}$ \\
\hline & & Chinka & 137 & 14 \\
\hline \multirow[t]{2}{*}{ Lere } & Lere & Mariri & 228 & 23 \\
\hline & & $\begin{array}{c}\text { Gure } \\
\text { Dama-kasuwa }\end{array}$ & $\begin{array}{l}321 \\
230\end{array}$ & $\begin{array}{l}32 \\
23\end{array}$ \\
\hline \multirow[t]{2}{*}{ Birni-Gwari } & Chikun & $\begin{array}{c}\text { Kujama } \\
\text { Gwagwada }\end{array}$ & $\begin{array}{l}250 \\
198\end{array}$ & $\begin{array}{l}25 \\
20\end{array}$ \\
\hline & & Kakau-daji & 168 & 17 \\
\hline Maigana & Kudan & $\begin{array}{c}\text { Doka Kudan } \\
\text { Dandubus } \\
\text { Pabea }\end{array}$ & $\begin{array}{l}201 \\
122 \\
131\end{array}$ & $\begin{array}{l}19 \\
12 \\
13\end{array}$ \\
\hline Total & 4 & 12 & 2423 & 242 \\
\hline
\end{tabular}

Source: Kaduna State Agricultural Development Project (KADP) (2014).

measure in naira value. The expected effect of households'

Poverty status: To determine their poverty status, information on both quantifiable and non-quantifiable factors of household expenditure was elicited. These include:

Household expenditure: Household expenditure refers to all spending on goods and services intended for consumption. It includes payment by the household for goods and services supplied accommodation, education, health, transportation, poverty on crop productivity will below

\section{Method of Data Analysis}

Descriptive statistics such as frequencies, percentages and arithmetic mean and inferential statistic (Foster, Greer and Thorbecke, multiple regression model and Total Factor Productivity (TFP). The t-value of the OLS regression results communication, clothing, utility supplies, bills and food. was used to test the hypotheses of the study.

Reardon. T. and Vosti, S. A. (1995). This was computed and

Foster, Greer and Thorbecke indices were used to determine the poverty status of the farmers, while descriptive statistics was used to determine strategies adopted in mitigating poverty. Adopting the model used by de Janvry (2010), FGT poverty index is given as:

$\mathrm{P} \alpha=\frac{1}{N} \sum_{i=1}^{q}\left(\frac{Z-y_{1}}{z}\right)^{\alpha}$

Where;

$\mathrm{P} \alpha=$ Poverty Index; $\mathrm{N}=$ total population; $\mathrm{q}=$ the number of poor (i.e. households below the poverty line); $\mathrm{z}=$ the poverty line for the household (two-third of Mean Per Capita Household Expenditure (MPCHE) of the farmers; yi = income of $i t h$ household $\alpha=$ poverty aversion parameter which takes the value $0,1,2$ representing incidence, depth and severity of the poverty, respectively. The $2 / 3$ means per capita expenditure is referred to as the moderate poverty line, while its $1 / 3$ is referred to as the core poverty line. This study was however, limited to the moderate poverty line because, because it closely approximates the $\$ 1 /$ day international poverty line (NBS, 2007).

$\alpha=$ degree of poverty aversion

Per capita expenditure $=$ Total expenditure

household size

Mean per capita household expenditure (MPCHE) $=\frac{\text { Total household PCE }}{\text { Total number of Households }}$

The categorization of respondents based on the poverty line is given as:

Extreme poor: those spending $<1 / 3$ of MPCHE; Moderately poor: those spending $<2 / 3$ of MPCHE; Non-poor: those spending $>$ $2 / 3$ of MPCHE.

Tobit regression model: The Tobit model is a statistical model proposed by James Tobin in 1958. It describes the relationship between a non-negative dependent variable $\mathrm{y}_{\mathrm{i}}$, and independent variables $\mathrm{x}_{\mathrm{i}}$. The Tobit model is defined as a latent variable model and is mathematically expressed as:

$$
\begin{aligned}
& y^{*}=\beta_{1}+\beta_{2} x_{i}+\varepsilon_{i} \\
& y_{i}=1 \text { if } \quad y^{*} \geq 0 \text { (i.e., the poverty index is "high enough") }
\end{aligned}
$$


$y_{i}=0$ if $y^{*}<0$ (i.e., the poverty index is not "high enough")

The latent variable $y^{*}$ satisfies the classical linear assumption of normality and homoscedastic distribution with a linear condition mean.

The Tobit model in its implicit form is specified as:

$\mathrm{Y}=\mathrm{f}\left(\mathrm{X}_{1}, \mathrm{X}_{2}, \mathrm{X}_{3} \mathrm{X}_{4}, \mathrm{X}_{5}, \mathrm{X}_{6}, \mathrm{X}_{7}, \mathrm{X}_{8}, \mathrm{X}_{9}\right)$

The explicit form of the Tobit model is expressed as:

$\mathrm{Y}=\alpha+\beta_{1} \mathrm{X}_{1}+\beta_{2} \mathrm{X}_{2}+\beta_{3} \mathrm{X}_{3}+\beta_{4} \mathrm{X}_{4}+\beta_{5} \mathrm{X}_{5}+\beta_{6} \mathrm{X}_{6}+\beta_{7} \mathrm{X}_{7}+\beta_{8} \mathrm{X}_{8}+\beta_{9} \mathrm{X}_{9}+\mathrm{e}$

Where;

$\mathrm{Y}^{*}=$ Poverty Status of the farmers $\left(\mathrm{Y}^{*}=0\right.$ when household is not poor and $\mathrm{Y}^{*}=\mathrm{Y}_{\mathrm{i}}$ when household is poor)

The independent variables are defined as:

$\mathrm{X}_{1}=$ Age of the farmers (years), $\mathrm{X}_{2}=\operatorname{Sex}($ male $=1$, female $=0), \mathrm{X}_{3}=$ Education (years)

$\mathrm{X}_{4}=$ Marital status $\left(1\right.$ if married and 0 otherwise), $\mathrm{X}_{5}=$ Household size (No), $\mathrm{X}_{6}=$ Farm size $(\mathrm{Ha}), \mathrm{X}_{7}=$ Farming experience (years), $\mathrm{X}_{8}=$ Income per annum ( $), \mathrm{X}_{9}=$ Amount of credit $(\mathrm{N})$

\section{RESULTS AND DISCUSSION}

\section{Socio-economic Characteristics of the Respondents}

The results presented in Table 2 show that, majority (51\%) of the crop farmers were within the age group of 40 years and above, with the mean age of 45 years, implying that farmers were in their productive stage of life and have the capacity of carrying out agricultural production. This result agrees with the findings of Ajah and Ajah (2014) who reported mean age of rice crop farmers in the country as 44 years. Results on gender distribution showed that majority $(84.7 \%)$ of the farmers were male while $(15.3 \%)$ were female implying that male farmers dominated agricultural activities in the area. This study is in tandem with the findings of Okere and Shittu (2012) which revealed that the males dominated the work force in Nigeria's agricultural rural areas.

Results in Table 2 reveal that majority $(87.1 \%)$ of the farmers were married, while $12.9 \%$ were single, divorced or separated. This implies that there were more married crop farmers with some level of family responsibility in the area. This finding is in agreement with that of (Ugwuja et al. 2011) who reported that $88.7 \%$ of the farmers in Ekiti State were married. Findings of this study shows that majority $(80.6 \%)$ of the farmers had formal education. This implied that literacy level in the study area was high. This result is in consonances with the findings of Awoniyi and Salma (2012) who pointed out that high educational level of farm household could increase income earnings and reduce poverty level. About $86 \%$ of the farmers had more than 11 years of farming experience in the study area with a mean of 22 years and had farm size which ranges between $1.1-2.0$ hectares with a mean farm size of 3.4 hectares. This finding is in line with the work of Oyekale and Idjesa (2009) who reported a mean farming experience of 20 years of maize crop farmers in River State, Nigeria.

The result in Table 2 shows that, the mean household size of 11 persons. This implied that the household size in the study area was fairly large and could negatively influence the expenditure pattern of the household especially on food consumption. Large family size is important in subsistent agricultural production especially within the rural setting. (Odoemenem and Obinne,2015) This is in line with the findings of Okere and Shittu (2012) who affirmed that larger households could experience poverty than smaller sized households. The result of the finding in Table 2 indicated that, $(50.8 \%)$ of the farmers acquired their land through inheritance which could lead to farmland fragmentation while majority $(66.1 \%)$ of the farmers indicated that their primary occupation was farming. This implied that farming was the pre-dominant occupation in the study area as those who engaged in other form of occupation still practice farming as their secondary occupation. 
Table 2: Distribution of Socio-economic characteristics of food crop farmers

\begin{tabular}{|c|c|c|c|}
\hline Variables & Frequency & Percentage & Mean \\
\hline Age (Years) & & & 45 \\
\hline$<21$ & 6 & 2.5 & \\
\hline $21-30$ & 30 & 12.4 & \\
\hline $31-40$ & 82 & 33.9 & \\
\hline$>40$ & 124 & 51.2 & \\
\hline \multicolumn{4}{|l|}{ Sex } \\
\hline Female & 37 & 15.3 & \\
\hline Male & 205 & 84.7 & \\
\hline \multicolumn{4}{|l|}{ Marital Status } \\
\hline Single & 12 & 5.0 & \\
\hline Married & 211 & 87.1 & \\
\hline Widower & 13 & 5.4 & \\
\hline Divorced & 6 & 2.5 & \\
\hline \multicolumn{4}{|l|}{ Educational Status } \\
\hline Non Formal & 47 & 19.4 & \\
\hline Primary & 46 & 19.0 & \\
\hline Senior Secondary & 80 & 33.1 & \\
\hline Tertiary & 69 & 28.5 & \\
\hline Farming Experience (Years) & & & 22 \\
\hline $1-5$ & 8 & 3.3 & \\
\hline $6-10$ & 25 & 10.3 & \\
\hline $11-15$ & 36 & 14.9 & \\
\hline$>15$ & 173 & 71.8 & \\
\hline Household Size & & & 11 \\
\hline $1-5$ & 52 & 21.5 & \\
\hline $6-10$ & 119 & 49.1 & \\
\hline$>10$ & 71 & 29.4 & \\
\hline Farm Size (Hectare) & & & 3.4 \\
\hline $0.1-1.0$ & 14 & 5.8 & \\
\hline $1.1-2.0$ & 104 & 43.0 & \\
\hline$>2.00$ & 124 & 51.2 & \\
\hline \multicolumn{4}{|l|}{ Land Ownership } \\
\hline Inheritance & 123 & 50.8 & \\
\hline Purchase & 46 & 19.0 & \\
\hline Rent/Lease & 67 & 27.7 & \\
\hline Gift & 6 & 2.5 & \\
\hline \multicolumn{4}{|l|}{ Primary Occupation } \\
\hline Farming & 160 & 66.1 & \\
\hline Gathering & 2 & 0.8 & \\
\hline Trading & 35 & 14.5 & \\
\hline Civil Servant & 40 & 16.5 & \\
\hline Artisan & 4 & 1.7 & \\
\hline Agro-processing & 1 & 0.4 & \\
\hline Total & 242 & 100.0 & \\
\hline
\end{tabular}

Source: Field Survey, 2016

Institutional variables assessed by the food crops farmers Cooperative membership of the farmers

The result in Table 3 revealed that, majority $(62.8 \%)$ of the farmers do not belong to cooperative, while $37.2 \%$ were members of cooperative societies implying low participation of cooperative membership in the study area. This could lead to none exposure to vital information as well as lack of access to production inputs through cooperative societies.

\section{Access to credit of the farmers}

Access to credit will go a long way in improving individual farm enterprise in terms of agricultural production. As revealed in Table 3, majority of $(86.0 \%)$ of the farmers had no access to credit; while $14.0 \%$ had access to credit which implied that access to credit is a problem in the study area. Access to agricultural credit has the propensity to break the vicious cycle of poverty and raise the purchasing power of farm households. Farmers Sources of Credit

The result in Table 3 shows that, majority (86.0\%) of the farmers had no access to credit as earlier indicated, hence have no source of credit. However, for those that have access to credit in the study area, $7.0 \%$ sourced their credit through cooperative, $4.5 \%$ through agricultural bank, $1.7 \%$ through Kaduna Agricultural Development Project (KADP) and Fadama Project, while paltry $0.8 \%$ of the farmers' source their credit through commercial banks. 
Table 3: Institutional variables assessed by the farmers $(n=242)$

\begin{tabular}{lcc}
\hline Variables & Frequency & Percentage \\
\hline Cooperative & 152 & 62.8 \\
Not member & 90 & 37.2 \\
Member & & \\
Access to Credit & 208 & 86.0 \\
No Access & 34 & 14.0 \\
Access & & 7.0 \\
Sources of credit & 17 & 4.5 \\
Cooperative & 11 & 1.7 \\
Agric. Bank & 4 & 0.8 \\
KADP / Fadama & 2 & 86.0 \\
Commercial bank & 208 & \\
None & & \\
\hline
\end{tabular}

Source: Field Survey, 2016

\section{Determination of poverty line}

The result in Table 4 gives a clear presentation of the estimation of the poverty line that was used to determine the poverty status of the farmers in the study area. The poverty line formed the basis for further analysis. The Foster-Greer-Thorbecke (FGT) class of poverty measures was employed to estimate the poverty status of the farmers in the study area. Following the adoption of Foster, Greer and Thorbecke measures, household total expenditure was used to determine household poverty status. The result in Table 4 show household food and non-food expenditure, total expenditure, per capita and mean per capita expenditure and the poverty line. The poverty line was constructed as two-thirds of the mean per capita household expenditure (MPCHE) of all households. This approach has been used by several researchers and institutions (NBS, 2012; Oni and Yusuf, 2008; Oyakhilomen and Kehinde, 2016) as a measure of welfare. Households were then classified into their poverty status based on the poverty line. Hence, non-poor households were those whose per capita expenditure was above or equal to two-third of the mean per capita expenditure of all households while those whose per capita expenditure was below two-thirds of the mean per capita expenditure were classified as poor. Based on this, the poverty line constructed as two-third of the mean per-capita expenditure of all the households was N14039.2. This implies that households whose monthly per capita expenditure fell below 14039.2 were classified as poor while households whose per capita expenditure equaled or was above the poverty line were classified as non- poor.

Table 4. Determination of households' poverty line

\begin{tabular}{lc}
\hline Items & Amount(\#) \\
\hline Household food expenditure & 1680700 \\
Household non-food expenditure & 16493101 \\
Household total expenditure & 17173601 \\
Per capita household expenditure (PCHE) & 1955859.82 \\
Mean Per capita household expenditure (MPCHE) & 19558.6 \\
2/3 MPCHE (Poverty line) & 14039.2 \\
\hline
\end{tabular}

Source: Field Survey, 2016

\section{Poverty indices of the farm households}

The poverty profile of households (poverty headcount index or incidence $\left(\mathrm{P}_{\mathrm{o}}\right)$, poverty gap or depth $\left(\mathrm{P}_{1}\right)$ and squared poverty gap or severity $\left(\mathrm{P}_{2}\right)$ were calculated (Table 5$)$. The headcount index (poverty incidence) in the study area was 0.51 implying that the proportion of the farming households whose per capita expenditures fell below the poverty line was $51 \%$. The Table shows that $51 \%$ of the farm households in the study are poor while $49 \%$ are non-poor. This result is in line with the findings of Oyakhilomen and Kehinde, (2016) on farm households' livelihood diversification and poverty alleviation in Giwa Local Government Area of Kaduna State, who reported that the poverty line was $\$ 13,039.10$ (monthly). Adekoyo (2014) reported that poverty is higher among male headed households who depend solely on agriculture for livelihood. More so, Asogwa et al. (2012) posited that poverty is disproportionately concentrated among households whose primary livelihood lie in agricultural activities. The poor are conventionally defined as the population that falls below a certain poverty line (Reardon and Vosti, 1995). Poverty Gap (depth) ( $\left.\mathrm{P}_{1}\right)$, usually referred to as the depth of an average poor person from the poverty line. Poverty gap was 0.28 , and this implies that the poor rural households require $28 \%$ of the poverty line to escape from poverty group. It is a measure of the poverty deficit of the entire population. Poverty Severity Index $\left(\mathrm{P}_{2}\right)$ which measures the distance between two poor persons was found to be 0.12 . Implies that the severity of the poverty among the households in the study area was $12 \%$. The poverty severity takes into account not only the distance separating the poor from the poverty line, but also the inequality among the poor. This result conforms to Asogwa et al. (2009) who reported a poverty severity of 0.15 in a study on poverty among farming households in Nigeria. 
Table 5: Poverty measures for the households' in the study area

\begin{tabular}{lc}
\hline Poverty measures & Result \\
\hline Poverty line ( $)$ & 14039.2 \\
Poverty headcount & 0.51 \\
Poverty gap & 0.28 \\
Poverty severity & 0.12 \\
Poor (\%) & 51 \\
Non-poor (\%) & 49 \\
\hline
\end{tabular}

Source: Field Survey, 2015

Factors influencing households' poverty in the study area Some of the factors influencing households' poverty in the study area were presented in Table 6. Tobit Regression model was used to determine the factors influencing rural poverty in the area. The Pseudo R-square (coefficient of determination) was 0.2846 indicating that about $28.5 \%$ variation in poverty incidence was explained by the explanatory variables included in the model. From the $\mathrm{z}$ - value of the regression, two independent variables (household size and income) out of the nine variables included in the model were found to be statistically significant at $1 \%$ level of probability. They both have negative coefficients and inversely related to incidence of poverty in the study area.

As shown in Table 6, the coefficient of household was negative $(-5.60)$ and statistically significant at $1 \%$ level of probability indicating an inverse relationship with the dependent variable. This implied that a unit increase in household size of the food crop farmers will decrease the poverty incidence of the respondents. For instance, as household size increases, the likelihood of being poor is reduced. This can be justified base on the fact that the more individuals in a household, the more the tendency to increase the number of workforce that source for income to cater for the need of the family thereby increasing the amount of income in that household. However, where the dependency ratio is high, large household size will increase the total consumption needs and thus increase the probability of being poor. This is in contrast to the work of Anigbogu et al. (2014) who reported that household size had a direct relationship with the poverty situation of their respondents in the study area. More so, the coefficient of income was negative $(-22.71)$ and significant at $1 \%$ level of probability indicating an inverse relationship with the dependent variable. This implies that a unit increase in income of the food crop farmers will decrease the poverty incidence of the respondents in the study area. For instance, the more they generate income from food crops production, the less their poverty situation. This finding is in agreement with the result of Asogwa et al. (2012) who reported that income had an inverse relationship with poverty severity, as income generation of farmers increases the probability and intensity of poverty decreases.

Table 6: Tobit regression coefficients of determinants of the Households' poverty

\begin{tabular}{llll}
\hline Variables & Coefficients & Standard error & Z-value \\
\hline Constant & -9.41316 & 3.66869 & $-2.57^{* * *}$ \\
Age & 0.06390 & 0.09168 & 0.70 \\
Sex & 1.04280 & 1.53719 & 0.68 \\
Education & -0.03240 & 0.11625 & -0.28 \\
Marital status & 1.01408 & 1.93009 & 0.53 \\
Household size & -0.62836 & 0.11227 & $-5.60^{* * *}$ \\
Farm size & -0.11461 & 0.17093 & -0.67 \\
Experience & -0.21887 & 0.08949 & -2.45 \\
Income & -0.00003 & $1.13 \mathrm{E}-06$ & $-22.71^{* * *}$ \\
Credit & $-7.77 \mathrm{E}-07$ & $1.55 \mathrm{E}-06$ & -0.50 \\
Sigma & 6.674543 & 0.4082013 & $16.35^{* * *}$ \\
Pseudo R-squared & 0.2846 & &
\end{tabular}

Source: Field Survey, 2016. *significant at 10\%, **significant at 5\%, ***significant at 1\%

\section{Strategies for mitigating poverty}

Strategies for mitigating poverty in the study area by the farmers were presented in Table 7. Diversification into commercial farming $(41.3 \%)$ was the most used strategy in mitigating poverty by the farmers in the study area. There was paradigm shift from subsistence to commercial farming in order to produce more foods for the teaming population. This is achieved through increased acreage and resources utilization. The next strategies adopted by the farmers for mitigating poverty was through personal savings (34.3\%), followed by involvement in non-farming activities $(28.5 \%)$ and engagement in agricultural marketing (25.6\%). It was also observed that borrowing from relatives $(21.5 \%)$ was used by the farmers, while the least used strategies in mitigating poverty is through asset accumulation (5.4\%). This implied that engagement in commercial farming and involvement in non-farm activities to generate extra income were some of the strategies for mitigating poverty by farmers in the study area. This study corroborate the findings of Simpa (2014) who stated that, major strategies used by the poor femaleheaded household rural farmers in coping with poverty are skipping of one or two meals a day which ranked 1 st $(96 \%$,), but they might eat leftover food in the morning and/or take 
snacks (garri in cold water and groundnut cake in the afternoon), however; take full and heavy dinner, quantity of meal reduced ranked 2nd (90\%), purchasing of less preferred food items ranked 3rd $(85 \%)$ and distress sales of growing crops $(80 \%$, ranked4th). Other coping strategies are engaging in wage labour (75\%, ranked 5th), borrowing from friends and relations $(60 \%$, ranked 6th), supplying farm labour for food items and not cash $(55 \%$, ranked 7 th), sales of assets other than growing crops (30\%, ranked 8th) and reducing expenditure on unproductive activities (28\%, ranked 9th). Engaging in wage labour with low pay as farm workers and house helps by members of the household help to complement the efforts of the household head.

Table 7: Farmers' strategies for mitigating poverty

\begin{tabular}{lcc}
\hline Variables & Frequency* $^{*}$ & Percentage $^{*}$ \\
\hline Mixed cropping & 33 & 13.6 \\
Involvement in non-farming activities & 69 & 28.5 \\
Asset accumulation & 13 & 5.4 \\
Diversification into commercial farming & 100 & 41.3 \\
Engagement in agricultural marketing & 62 & 25.6 \\
Personal savings & 83 & 34.3 \\
Borrowing from relatives & 52 & 21.5 \\
\hline
\end{tabular}

Source: Field Survey, $2016 . \quad$ *multiple response

\section{Constraints Faced by the crop farmers}

The result in Table 8. shows that the major constraints faced by the respondents includes: high cost of inputs (76.4\%), inadequate market linkages (65.7\%), and inadequate credit facilities (57.4\%), respectively. This finding is in agreement with Aniedu (2007) who posited that high cost of input is a constraint face by most farmers.

Table 8: Distribution of crop farmers based on their constraints

\begin{tabular}{|c|c|c|c|}
\hline Constraints & Frequency* & Percentages & Rank \\
\hline High cost of inputs & 185 & 76.4 & $1^{\text {st }}$ \\
\hline Inadequate credit facilities & 159 & 65.7 & $2^{\text {nd }}$ \\
\hline Inadequate market linkages & 139 & 57.4 & $3^{\text {rd }}$ \\
\hline Problem of pest and diseases & 119 & 49.2 & $4^{\text {th }}$ \\
\hline Small size of farmland & 117 & 48.3 & $5^{\text {th }}$ \\
\hline Inadequate labour supply & 98 & 40.5 & $6^{\text {th }}$ \\
\hline Inadequate extension services & 93 & 38.4 & $7^{\text {th }}$ \\
\hline Poor yield of farm produce & 84 & 34.7 & $8^{\text {th }}$ \\
\hline Inadequate information and communication & 53 & 21.9 & $9^{\text {th }}$ \\
\hline Complexity of farm technology & 41 & 16.9 & $10^{\text {th }}$ \\
\hline Small household size & 19 & 7.9 & $11^{\text {th }}$ \\
\hline
\end{tabular}

Source: Field Survey, 2016*signifies multiple response.

SUMMARY, CONCLUSION AND RECOMMENDATION Based on the empirical evidence from the findings of this study, it is concluded that majority of the farmers were married, educated, highly experienced and actively involved in crop production and most of the farmers were poor in the study area; poverty situation of the farmers shows that a little over half $(50.8 \%)$ were poor in the study area. Strategies adopted by the farmers to combat poverty are mostly through diversification into commercial farming, increased personal savings and involvement in non-farming activities. High cost of inputs, inadequate credit facilities and inadequate market linkages were the major constraints faced by the crop farmers in the study area. It was recommended that farmers should form rotating saving association to enable them have access to micro loan; rural crop farmer should be linked to the urban market through appropriate information channels such as extension agent and media to attract good value for their crops.

\section{REFERENCES}

Adamu, B.D and H.Y Michael (2019). Determinants of Poverty Status among Women Farmers in Development Exchange Centre Microcredit of Kaduna State, Nigeria. Journal of Agripreneurship and Sustainable Development, 2 (2), 194203.www.jasd.daee.atbu.edu.ng; 
Adekoyo. O. A. (2014). Analysis of Farm Households' Poverty Status in Ogun States, Nigeria. Asian Economic and Financial Review, 4(3), 325-340.

Adenomon, M. O and Oyejola, B. A, (2013). Impact of Agriculture and Industrialization on GDP in Nigeria: Evidence from VAR and SVAR Models. Munich Personal RePEc Archive. https://mpra.ub.uni-muenchen.de/75268/MPRA Paper No. 75268.Retrieved from internet on 4/09/2020.

Ajah, C. and Ajah, F. C (2014). Socioeconomic Determinant of Small-Scale Rice Farmers Output in Abuja; Nigeria. Asian Journal of Rural Development, 6 (4), 1 16-24.

Aniedu, O. C. (2007). Impact of Technological Change on Output, Income, Employment and Factor Shares in Potato Production in Plateau State, Nigeria. Unpublished PhD Thesis Submitted to the Department of Agricultural Economics, Michael Okpara University of Agriculture, Umudike.

Anighogu, T.U; Onwuteaka, C.I; Anyanwu, K.N. \& Okoli, M.I. (2014). Impact of Household Composition and anti-Poverty programmes on welfare in Nigeria. A comparative analysis. European Journal of Business and Social Sciences 3(5), 23-36

Asogwa, B. C; Okwoche. V. A and Umeh, J.C (2012). Analyzing the Determinants of Poverty Severity Among Rural Farmers in Nigeria: A Censored Regression Model Approach. American International Journal of Contemporary Resources, 2(5), 166176.

Awoniyi, O. A. and Salma, K. K. (2012). Non-Farm Income Diversification and Welfare Status of Rural Households in South West Zone of Nigeria. International Food Policy Research Institute (IFPRI) Paper. Pp. 1-14.

Bhalla. S. (2002). Imagine there's no country: Poverty, Inequality, and Growth in the era of Globalization. International Journal of Business Research 8 (4), 2-7.

de Janvry, A.(2010). Agriculture for Development: New Paradigm and Options for Success. Agricultural Economics, 41(51), 17-3

Folorunso, S. T (2016). Impact of Fadama III on Productivity, Food Security and Poverty Status of Root and Tubers Crops Farmers in North Central States of Nigeria. Unpublished PhD Thesis, Department of Agricultural Economics and Rural Sociology, Ahmadu Bello University, Zaria.

Igbaese, F. I and Okojie-Okoedo D. (2017). Food and Hunger Everywhere: Nigeria Paradox of Poverty. International Review of Business Research Papers, 6(4):90-100.

International Food Policy Research Institute (2018). From the Ground Up. Impact of Pro-Poor Community-Driven Development Project in Nigeria: 40-51.

Kaduna State Agricultural Development Project (KADP (2014). Annual Report, January-December.
National Bureau of Statistics (NBS), (2012) Nigeria poverty profile.

National multi-dimensional poverty index for Nigeria (2019). Mppn.org.retrieved from internet on 20/4/2020.

National Population Commission (2006). National Population and Housing Final Report Extraordinary Gazette.

Nwajinba, C. (2012). Does Agriculture have a future in southeast Nigeria? Inaugural lecture, No. 5. Imo State University Owerri, Nigeria

Nweke, F.L, Spencer, D.S.C and Lynam J.K (2015). The Cassava Transformation. Michigan State University Press, Michigan.

Odoemenem, I.U and Obinne, C.P.O (2015). Assessing the Factors Influencing the Utilization of Improved Cereal Crop Production Technologies by Small-Scale Farmers in Nigeria. Indian Journal of Science and. Technology, 3(1):180-183.

Ogunlela, V.B and Ogungbile, A.O (2014). Alleviating Rural Poverty in Nigeria: A Challenge for National Agricultural Research. Journal of Food Agriculture and Environment. Retrieval on 31/08/2020 from https://www.researchgate.net/publication/238798606

Okere, C. P.and Shittu, A. M. (2012). Patterns and Determinants of Livelihood Diversification among Farm Households in Odeda Local Government Area, Ogun State, Nigeria. Paper Presented at The Nigerian Association of Agricultural Economist Conference Held at Obafemi Awolowo University, Ile-Ife between 25-27 September, 2012. Theme: Agriculture in the National Transformation Agenda: The Policy Mix.

Oladimeji, Y. U (2014). Analysis of Poverty Status of Rural Artisanal Fishery Households in Kwara State, Nigeria. Unpublished PhD Thesis, Ahmadu Bello University Zaria, Kaduna State. Nigeria

Oni, K. C. (2008). Transforming Agricultural Potentials to Wealth in Northern Nigeria. Invited Paper Presented at the Northern Nigeria Economic and Investment Summit, Abuja, October, 2008.

Oni, O. A and Yusuf. N (2007). Determinants of Expected Poverty among Rural Households in Nigeria. Unpublished PhD Thesis, Department of Agricultural Economics, University of Ibadan.

Oyakahilomen, O and Kehinde, K.O (2016). Farm Households Diversification and Poverty Alleviation in Giwa Local Government Area of Kaduna State, Nigeria.The Journal of Sustainable Development. 15(1), 219-232. Retrieved from internet on 11/8/2019.

Oyekale, A. S. and Idjesa, E. (2009). Adoption of Improved Maize Seeds and Production Efficiency in Rivers State, Nigeria. 
Academic Journal of Plant Science, 2(1): 44 - 50.

Reardon. T. and Vosti, S. A. (1995). Links between Rural Poverty and the Environment in Development Countries: Asset Categories and Investment Poverty. World Development, 23(9), 1495-1506.

Reddy, S. G. \& Kakwani, N. (2006). Measuring the Impact of Price changes on Poverty. UNDP International Poverty Centre, Working Paper No. 33, November 2006. Brasilia: UNDP

Reddy, S. G. \& Pogge, T. (2006). The extend, distribution and trend of Global income poverty.

Reddy, S. G. (2009). Real income stagnation of countries: 19602001, Journal of Development studies. 45(1), 1-23.

Rosegrant, M.W.; Cline, S.A.; Li, W.; Sulser, T.B. and ValmonteSantos, R.A. (2005). Looking Ahead: Long-term Prospects for Africa's Agricultural Development and Food Security. 2020 Discussion Paper 41, International Food Policy Research Institute, Washington, D.C., $60 \mathrm{pp}$.

Simonya, J. B. (2010). Impact Analysis of Fadama II Project on
Income and Productivity of Beneficiaries in Kaduna State. Unpublished PhD Thesis, Department of Agricultural Economics and Rural Sociology Ahmadu Bello University, Zaria, Kaduna State.

Simpa, J.O (2014). Poverty Determinants among FemaleHeaded Household Rural Farmers in Nasarawa State, Nigeria. www.patnsukjournal.net/currentissue10(1):93-109. Retrieved October, 172019.

Ugwuja, V.C., Adesope, O. M., Odeyemi, T. J., Ifeannyi-Obi, C. Cand Nkwakasi. R. (2011). Socioeconomic Characteristics of Farmers as Correlates of Fertilizer Demand in Ekiti State, South West Nigeria: Implications for Agricultural Extension. Greener Journal of Agricultural Science 1 (1), 48-54

World Bank. (2019). Nigeria Economic Report. Retrieved on www.imf.org July 2019

Yahaya, A. Y. (2009). Rural Women Participation in Agriculture and Food Production in Asa L.G.A. Kwara State. Unpublished M.Sc Dissertation, Department of Geography, University of Ilorin 